\title{
Cloning and characterization of Edwardsiella ictaluri proteins expressed and recognized by the channel catfish Ictalurus punctatus immune response during infection
}

\author{
Michelle M. Moore* , Denise L. Fernandez ${ }^{* *}$, Ronald L. Thune ${ }^{* * *}$ \\ Departments of Veterinary Science, Louisiana State University Agricultural Center and Pathobiological Sciences, \\ School of Veterinary Medicine, Louisiana State University, Baton Rouge, Louisiana 70803, USA
}

\begin{abstract}
An Edwardsiella ictaluri expression library was screened for clones expressing antigenic E. ictaluri proteins using anti-E. ictaluri serum, which resulted in the isolation of 32 clones. The clones were partially characterized and 4 were selected for complete analysis. Sodium dodecyl sulfate polyacrylamide gel electrophoresis (SDS-PAGE), 2-dimensional PAGE, Western blotting, and DNA sequencing were used to analyze expressed antigenic proteins and encoded genes. Sequence analysis identified 4 putative open reading frames (ORFs) in the insert of Clone 4d6, which corresponded to antigenic acidic proteins of 55, 20 and $18 \mathrm{kDa}$ expressed by both the clone and E. ictaluri cells. The predicted gene products of these ORFs were similar to several products of the imp locus of Rhizobium leguminosarum bv. trifolii. The imp locus of $R$. leguminosarum contains 14 genes that encode proteins involved in a putative temperature-dependent protein secretion system. In addition there was significant amino acid identity for a variety of hypothetical proteins from $R$. solanacearum, Ps. aeruginosa, A. tumefaciens, Y. pestis, and Salmonella typhimurium. Overlapping inserts of Clones 1.4, 5d2, and 5d3 encoded ORFs similar to Escherichia coli partial genes serA and pgk, and complete genes rpiA, iciA, yggE, yggB and fda. These genes encode D-3-phosphoglycerate dehydrogenase $(\operatorname{ser} A)$, ribose 5-phosphate isomerase (rpiA), a specific inhibitor of chromosomal initiation of replication (iciA), a hypothetical protein $(\mathrm{yggE})$, a protein involved in responses to osmotic stress $(y g g B)$, fructose 1,6-bisphosphate aldolase ( $f d a)$, and phosphoglycerate kinase (pgk). Cloned antigenic E. ictaluri proteins of 33,27, 35 and $45 \mathrm{kDa}$ appeared to be products of the ORFs similar to yggE, rpiA, iciA, and fda respectively. All the cloned antigenic proteins were recognized by antiserum from catfish that had recovered from enteric septicemia of catfish (ESC), indicating that these antigens are expressed during the infectious process. The cloned antigenic proteins were subsequently evaluated as subunit vaccines for protection against wild-type E. ictaluri. All vaccine treatments were protective against $E$. ictaluri in catfish, but results were inconclusive due to high levels of cross-reactive protection afforded by the E. coli host strain of the cloning vector.
\end{abstract}

KEY WORDS: Edwardsiella ictaluri $\cdot$ Cloning $\cdot$ Antigenic proteins $\cdot$ Channel catfish $\cdot$ Vaccination Resale or republication not permitted without written consent of the publisher

Present addresses:

${ }^{*}$ National Oceanic \& Atmospheric Administration, National Marine Fisheries Service, Alaska Fisheries Science Center, Resource Assessment \& Conservation Engineering Division, 7600 Sand Point Way NE, Seattle, Washington 98115-0070, USA

**Pennington Biomedical Research Center, Louisiana State University, Baton Rouge, Louisiana 70808, USA

${ }^{* * *}$ Corresponding author. E-mail: thune@mail.vetmed.lsu.edu

\section{INTRODUCTION}

Edwardsiella ictaluri, the causative agent of enteric septicemia of catfish (ESC), is the primary bacterial pathogen of commercially produced channel catfish Ictalurus punctatus in the southeastern United States. Mortality losses and treatment costs are estimated to be 19 million dollars annually (Thune et al. 1997b). 
Although ESC is currently treated with antibiotics, increases in the number of antibiotic-resistant $E$. ictaluri strains are reducing the effectiveness of these drugs (Johnson 1991). In addition, disease-related anorexia further reduces antibiotic efficacy because the drugs must be delivered orally (MacMillan 1985).

Catfish that survive an Edwardsiella ictaluri infection are generally assumed to be resistant to ESC when they recover (Klesius \& Horst 1991). The bacterium is considered a good candidate for vaccine development because it has a very high serologic homogeneity (Plumb 1988, Plumb \& Vinitnantharat 1989, Bertolini et al. 1990), although reported efficacy using killed $E$. ictaluri bacterins has been equivocal at best (Plumb et al. 1986, Saeed \& Plumb 1986, Thune et al. 1993, 1997b)

Protection from ESC does not correlate with antibody production unless titers are very high (Vinitnantharat \& Plumb 1993, Thune et al. 1997a,b), but antibodies do appear to play a role in immunity to Edwardsiella ictaluri when combined with phagocytic cells (Scott et al. 1985, Sheldon \& Blazer 1991, Waterstrat et al. 1991, Wise et al. 1993, Shoemaker et al. 1997). Recent reports indicate the efficacy of live, attenuated strains in protecting catfish from subsequent disease (Cooper et al. 1996, Lawrence et al. 1997, Klesius \& Shoemaker 1999, Thune et al. 1999), presumably because a strong cell-mediated immune response is generated. The antigens responsible for effective antibody and cell-mediated responses have not been identified.

Efforts are now required to define immunity to ESC, including the identification of important protective antigens. Identification and characterization of the antigens that are expressed during an infection may lead to a better understanding of the host immune responses, as well as bacterial mechanisms of pathogenicity. The goals of this study were to identify and characterize antigenic proteins of Edwardsiella ictaluri expressed during the infectious process, and evaluate the protective capabilities of those antigens.

\section{MATERIALS AND METHODS}

Bacterial strains and growth conditions. Edwardsiella ictaluri Virulent Isolate 93-146 was grown on tryptic-soy agar with sheep's blood (TSA II), brainheart infusion broth (BHI), or E. ictaluri-defined minimal media broth (MM19; Collins \& Thune 1996) at 25 to $28^{\circ} \mathrm{C}$. The Escherichia coli strains XL1-Blue MRF' and XLOLR (Stratagene) were grown in Luria-Bertani (LB) or NZY media at $37^{\circ} \mathrm{C}$ with the appropriate antibiotics (Sambrook et al. 1989). Fusion-protein expression was induced in clones by adding isopropyl- $\beta$-D-thio- galactopyranoside (IPTG) to $2 \mathrm{~h}$ LB broth cultures at a final concentration of $1 \mathrm{mM}$ IPTG, followed by overnight incubation at $37^{\circ} \mathrm{C}$.

Construction of Edwardsiella ictaluri genomic expression library. An E. ictaluri genomic library was constructed by ligating a Sau3A I partial digest of genomic DNA into the BamHI site of the $\lambda$ ZAP Express $^{\mathrm{TM}}$ expression vector (Stratagene). The $\lambda$ ZAP Express $^{\mathrm{TM}}$ phage were grown in XL1-Blue MRF' and the phagemids were excised in XLOLR according to the manufacturer's protocol. Control phagemid without insert was also excised into XLOLR and designated XLOLR pBK-CMV. The resulting E. ictaluri plasmid library was grown on LB-agar and replicated onto nitrocellulose membranes following the methods of Ausubel et al. (1994). Membranes were incubated on LB-Kanamycin (Kan) plates at $37^{\circ} \mathrm{C}$ overnight. Each membrane was replicated onto several other membranes, which were transferred to LB-Kan-IPTG plates, with or without X-gal, to induce protein expression and screen for colonies with inserts.

Bacterial cell preparations. Whole-cell lysates (WCLs) of Edwardsiella ictaluri and Escherichia coli XL1-Blue MRF' were prepared as described previously (Moore \& Thune 1999). Briefly, washed cell pellets were resuspended in a standardized volume of sterile deionized water, sonicated, and centrifuged. The cell pellet was discarded and the supernatant was brought to a final concentration of $0.01 \%$ thimerosal with $10 \%$ thimerosal stock, aliquoted, and frozen at $-80^{\circ} \mathrm{C}$ (Moore \& Thune 1999). Induced clones were treated in 1 of 3 ways: (1) For SDS-PAGE, $500 \mu$ of small-scale induced cultures were aliquoted into sterile microfuge tubes and centrifuged at $16000 \times g$ for $5 \mathrm{~min}$ at room temperature; supernatant was discarded and cell pellets were stored at $-20^{\circ} \mathrm{C}$ until use. (2) For 2D-PAGE, antiserum adsorbtion, and vaccine trials, induced cultures were processed as described above, but WCLs were not centrifuged following sonication. (3) Uncentrifuged clone WCLs were used in vaccine trials and to pre-adsorb cross-reactive antibodies from antisera. Prior to analysis by 2D-PAGE, clone WCLs were thawed, aliquoted into sterile microfuge tubes, and centrifuged at $16000 \times g$ for $10 \mathrm{~min}$ at room temperature. The pellet was discarded and the supernatant was aliquoted into fresh tubes and either analyzed or frozen at $-20^{\circ} \mathrm{C}$ until analysis.

Edwardsiella ictaluri antisera. To obtain ample high-titer antisera for initial library screening, a goat was hyper-immunized by vaccinating with E. ictaluri WCL in Freund's complete adjuvant, followed by 3 weekly booster injections in Freund's incomplete adjuvant. The E. ictaluri cells were grown in MM19 broth. Preliminary Western blots of the Escherichia coli strains showed significant recognition by the goat $E$. 
ictaluri antiserum, presumably due to either previous exposure to $E$. coli or to cross-reactivity between $E$. ictaluri and E. coli antigens. Consequently, the goat antiserum used for screening the E. ictaluri library was pre-adsorbed with E. coli XL1-Blue MRF' WCL. Preadsorption of cross-reactive antibodies was accomplished by mixing antiserum with XL1-Blue $\mathrm{MRF}^{\prime}$ WCL in 2 adsorbtion steps. For the first adsorbtion, a 1:6 mixture was incubated at room temperature for $2 \mathrm{~h}$ on a rocker, held overnight at $4^{\circ} \mathrm{C}$, and centrifuged at $10000 \times g$ for $5 \mathrm{~min}$ at room temperature. The supernatant was transferred to sterile tubes and the remaining WCL was added, resulting in a final adsorbtion concentration of 1:12. The incubation and centrifugation steps were repeated, and the supernatant was brought to $0.01 \%$ thimerosal with $10 \%$ stock, and stored at $-80^{\circ} \mathrm{C}$ until use. The pre-adsorbed goat antiictaluri serum was designated GAI. To remove antibodies to E. ictaluri lipopolysaccharide (LPS) that might interfere with antibody recognition of $E$. ictaluri proteins, the GAI was further pre-adsorbed with a final concentration of $1 \mathrm{mg}^{-1} \mathrm{ml}$ E. ictaluri LPS of confirmed purity isolated from Strain ATCC 33202 (Newton \& Triche 1993). The LPS-adsorbed GAI, designated GAILA, was used to probe Western blots of E. ictaluri. For specific-clone adsorption studies, GAI-LA was further adsorbed with an equal part of induced control WCL of XLOLR pBK-CMV, designated pBK, or WCL from a particular induced clone expressing E. ictaluri proteins.

Channel catfish Edwardsiella ictaluri antiserum was obtained from fish that had recovered from natural $E$. ictaluri infections at 5 catfish farms in Louisiana. Pooled convalescent catfish serum (CCS) was made up of sera from 15 fish (3 from each farm) that had high enzyme-linked immunosorbent assay (ELISA) and agglutination titers of E. ictaluri antibodies. The CCS was pre-adsorbed with an equal part of E. ictaluri LPS as described above. Normal catfish serum (NCS), collected and pooled from catfish hatched and reared in the Specific-Pathogen-Free (SPF) Laboratory at the School of Veterinary Medicine, Louisiana State University, was used as the negative antibody control.

Antibody screening of Edwardsiella ictaluri expression library. Induced replica membranes were screened for antigen expression with GAI antiserum. Colonies were lysed following the chloroform-based method of Sambrook et al. (1989). Indirect antibody screening was performed using enhanced chemiluminescent Western blotting (ECL; Amersham International) with GAI as the primary antibody and a monoclonal anti-goat/sheep IgG ( $\lambda$-chain-specific) horseradish peroxidase conjugate as the secondary antibody (GT-34, Sigma). Positive colonies were picked, cultured, and re-screened until each positive clone was in pure culture. Stocks of each clone were prepared and stored in $20 \%$ glycerol at $-80^{\circ} \mathrm{C}$.

Polyacrylamide gel electrophoresis. Miniature discontinuous SDS-PAGE was performed in $12 \%$ gels following the manufacturer's protocol (Bio-Rad). Mini 2DPAGE was performed using previously described methods (Moore \& Thune 1999). Following SDS and 2D-PAGE, proteins were either stained or transferred to nitrocellulose membranes. The SDS-PAGE gels were stained with Coomassie blue (Sigma) and 2D-PAGE gels were stained with a rapid silver stain (ICN Radiochemicals) as described previously (Moore \& Thune 1999). The molecular weights of antigenic proteins expressed by each clone were estimated using low molecular weight standards (Bio-Rad) following the methods of Bollag \& Edelstein (Bollag \& Edelstein 1991). Isoelectric focusing standards (Bio-Rad) showed that the $\mathrm{pH}$ gradient of the 2D-PAGE gels ranged from $\mathrm{pH} 4.5$ to 6.6. The pI (isoelectric point) values estimated for each cloned protein are subjective approximations reported for comparative purposes only.

Western blot analysis. Western blotting was performed following the ECL (Amersham) protocol. If CCS was the primary antibody, secondary antibody was monoclonal anti-catfish IgM (mAb 9E1; Miller et al. 1987) and tertiary antibody was affinity-isolated, antigen-specific goat anti-mouse IgG ( $\lambda$-chain specific) horseradish peroxidase conjugate (Sigma). To aid spot and band identification, nitrocellulose membranes were stained with a colloidal gold total protein stain (Bio-Rad) following immunodetection. Autoradiographs of Western blots were compared with stained nitrocellulose membranes and stained gels to confirm identification of antigenic spots and determine their location among non-antigenic proteins.

Plasmid analysis. Small-scale preparations of control pBK-CMV (cytamegalovirus) and plasmid DNA of each clone were obtained by alkaline lysis (Sambrook et al. 1989). Large-scale plasmid preparations were obtained by alkaline lysis using a Qiagen Plasmid Midi Kit (Qiagen Inc.). Plasmid preparations were either digested with Not I to linearize plasmids or doubledigested with Not I and Pst I or Pst I and Eco RI (New England Biolabs, Beverly, Massachusetts) to cut the insert from the plasmid. Fragment sizes were estimated in agarose gels using a $1 \mathrm{~kb}$ DNA ladder (Gibco BRL) as a size standard (Sambrook et al. 1989).

DNA and deduced protein-sequence analysis. Automated DNA sequencing was performed using the ABI PRISM $^{\mathrm{TM}}$ Dye Terminator Cycle Sequencing Ready Reaction Kit and an ABI Prism 310 Genetic Analyzer following the manufacturer's protocol (Perkin Elmer). Complete double-stranded sequence data was obtained using primers to the T3 and T7 RNA polymerase sites flanking the insert in the pBK-CMV vector, with 
subsequent primers produced from the generated sequences. The generated sequences were assembled, analyzed, and aligned with other sequences using the GCG Wisconsin Sequence Analysis Package ${ }^{\mathrm{TM}}$ Version 9.0 (Genetics Computer Group) and PC/Gene (IntelliGenetics). Generated sequences were compared to other known sequences using the Basic Local Alignment Search Tool (BLAST). The protein structure and amino acid sequence deduced from the generated DNA sequences were analyzed using both GCG and PC/Gene. Amino acid sequences and protein structures were analyzed using the Expert Protein Analysis System (ExPASy) available through the ExPasy molecular biology World Wide Web server of the Swiss Institute of Bioformatics (www.expasy.ch).

Channel catfish. Channel catfish egg masses were obtained from a commercial producer with no history of ESC outbreaks. The eggs were disinfected with 100 ppm free iodine and hatched in closed recirculating systems in the SPF laboratory at the School of Veterinary Medicine. Fish were reared on commercial catfish diets fed at $3 \%$ of their body weight per day until used for the challenge experiments.

Vaccine preparations. Sonicated WCLs were thawed $4 \mathrm{~d}$ prior to use, brought to a final concentration of $0.03 \%$ formalin, rocked on an aliquot mixer at $4^{\circ} \mathrm{C}$ overnight, then stored at $4^{\circ} \mathrm{C}$ until use as vaccine treatments. To confirm sterility, individual thioglycolate broth (Difco) tubes were inoculated with $100 \mu \mathrm{l}$ of each formalized WCL and incubated at $28^{\circ} \mathrm{C}$ for Edwardsiella ictaluri WCLs and $37^{\circ} \mathrm{C}$ for Escherichia coli WCLs.

Vaccination and challenge. Experimental SPF fish were transferred to a separate laboratory into 201 tanks supplied with a continuous flow of dechlorinated municipal water maintained at $25 \pm 1^{\circ} \mathrm{C}$ at a flow-rate of 300 to $400 \mathrm{ml} \mathrm{min}^{-1}$. Fish were randomly stocked at a density of 11 fish per tank and fed commercial catfish feed ad libitum every other day during a $4 \mathrm{wk}$ acclimation period and throughout the experiments. On the day of vaccination, tanks were randomly assigned to eight treatment groups with 3 replicate tanks per treatment. Fish $(31.5 \pm 3.49 \mathrm{~g})$ were anesthetized with tricaine methanesulfonate (MS-222; Argent Chemical Laboratories) and individually injected intramuscularly with $0.1 \mathrm{ml}$ of the assigned vaccine treatment. The 8 treatment groups included 2 saline controls, control WCLs of Edwardsiella ictaluri grown in BHI and MM19, WCL of induced control XLOLR pBK-CMV, and WCLs of Induced Clones $4 \mathrm{~d} 6,5 \mathrm{~d} 2$ and $5 \mathrm{~d} 3$. Booster injections of the same treatments were administered $28 \mathrm{~d}$ after initial vaccination.

Twenty-eight days following booster injections, fish in all treatments except 1 saline injected control were challenged with Edwardsiella ictaluri Strain 93-146 by immersion exposure. Briefly, water flow was stopped, tank volumes were lowered to $10 \mathrm{l}$, and $200 \mathrm{ml}$ of overnight $E$. ictaluri culture was added to achieve a final bacterial concentration of approximately $1 \times 10^{8}$ colony-forming units (CFU) per milliliter; water flow was resumed immediately after the culture was added. One saline-injected treatment group was exposed to $200 \mathrm{ml}$ sterile BHI broth as a control. Mortalities were recorded every $24 \mathrm{~h}$ post-exposure until there were no mortalities for 7 consecutive days. All dead fish were necropsied and kidney tissue was streaked for isolation on TSA II to confirm E. ictaluri as the cause of death. Cumulative daily percent mortality data for each tank was normalized with an arcsine square-root transformation (Neter et al. 1990), and analyzed by analysis of variance (ANOVA) followed by Tukey's multiple comparison at a significance level of $\alpha=0.05$ using the general linear models procedure in SAS Version 6.12 (SAS). Relative percent survival (RPS) was calculated using the formula RPS $=100 \times\{1-(\%$ mortality treatment $\div \%$ mortality controls $)\}$ as described by Amend (1981).

\section{RESULTS}

\section{Library screening}

Approximately 17200 CFU were screened with GAI, resulting in the entire library being screened approximately 2.2 times. A total of 99 potential positive colonies were picked, from which 32 confirmed positive colonies were isolated in pure culture. Clones were named and numbered based on the replicate number of the membrane from which the colony was originally picked.

\section{Selection of clones for further analysis}

Estimated sizes of the DNA inserts in plasmids isolated from the 32 positive clones ranged from 1.9 to $7.7 \mathrm{~kb}$. Cloned antigenic protein bands were detected in 27 of 32 clones in SDS-PAGE Western blots probed with either GAI or CCS. Clones were grouped based on the similarity of protein expression and restriction endonuclease analysis, and 9 dissimilar clones were chosen for sequence analysis. Comparisons of partial sequences generated using the flanking T3 and T7 primers of the cloning vector showed that several of the clones contained the same, similar or overlapping inserts of Edwardsiella ictaluri genomic DNA. Based on the partial DNA sequence data and protein expression analysis, 4 clones designated $4 \mathrm{~d} 6,1.4,5 \mathrm{~d} 2$ and $5 \mathrm{~d} 3$ were chosen for further characterization. Clone $4 \mathrm{~d} 6$ 
had a unique insert and expressed 3 cloned antigenic $E$. ictaluri proteins. Clones $1.4,5 \mathrm{~d} 2$ and $5 \mathrm{~d} 3$ had overlapping inserts and appeared to express some of the same cloned proteins based on molecular weights and isoelectric points. The DNA inserts of Clones 4d6, $5 \mathrm{~d} 2$ and $5 \mathrm{~d} 3$ were selected for complete double-strand sequencing. Antigenic proteins of the 4 selected clones were visualized in SDS and 2D-PAGE gels, and Western blots were probed with GAI and CCS. The results showed no difference in antigenic protein expression between IPTG-induced and non-induced clones, indicating that the proteins were under control of their own promoters. Results also showed that CCS was cross-reactive with a number of Escherichia coli proteins (Fig. 1C). Control Western blots showed that NCS contained no cross-reactive antibodies to $E$. coli proteins (data not shown).

To determine the relatedness of the cloned proteins to proteins actually expressed by Edwardsiella ictaluri cells, the GAI-LA was absorbed further with WCL from specific clones. Identical 2D-PAGE Western blots of $E$. ictaluri WCL were probed with GAI-LA, and specificclone adsorbed GAI-LA (SAG) of Clones 4d6, 1.4, 5d2, $5 \mathrm{~d} 3$ and the control pBK. The results showed no discernible differences between the E. ictaluri control blots probed with GAI-LA and SAG(pBK) or any of the Clone SAG with the exception of the blot probed with SAG(4d6). The results of the Western blot probed with SAG(4d6) are reported below.

\section{Analysis of Clone 4d6}

\section{Expressed Edwardsiella ictaluri proteins of Clone 4d6}

Compared to the pBK WCL control (Fig. 1A), silverstained 2D-PAGE gels of Clone 4d6 WCL showed the expression of 3 unique proteins of approximately 63, 20 and $18 \mathrm{kDa}$ (Fig. 2A). The $63 \mathrm{kDa}$ protein ran as a small, elongated brown spot with a pI of approximately 5.5. The $20 \mathrm{kDa}$ protein ran as a vertical doublet of 2 small, yellow spots with a pI of approximately 5.5. The $18 \mathrm{kDa}$ protein had multiple isoelectric isomers appearing as approximately 5 orange spots running together horizontally across the $\mathrm{pH}$ range, with a center tail extending up vertically so that the complex had the appearance of a large inverted ' $\mathrm{T}$ '. The $18 \mathrm{kDa}$ isoelectric isomers had pIs ranging from approximately 5.0 to 5.5. The 63, 20 and $18 \mathrm{kDa}$ unique protein spots were all detected strongly in 2D-PAGE Western blots probed with GAI, with the inverted ' $\mathrm{T}$ ' pattern of the isolelectric isomers of the $18 \mathrm{kDa}$ protein being apparent (Fig. 2B). All 3 cloned proteins were also detected in 2D-PAGE Western blots probed with CCS (Fig. 2C), indicating that they are expressed during an infection.
Relatedness of cloned proteins to proteins expressed by Edwardsiella ictaluri cells

In the SAG(4d6), specific antibodies against the cloned 63, 20 and $18 \mathrm{kDa}$ Edwardsiella ictaluri proteins were adsorbed out of the antiserum (Fig. 3). Comparisons between 2D-PAGE Western blots of E. ictaluri WCL probed with control SAG(pBK) and SAG(4d6) showed that 3 bands and 4 corresponding spots that
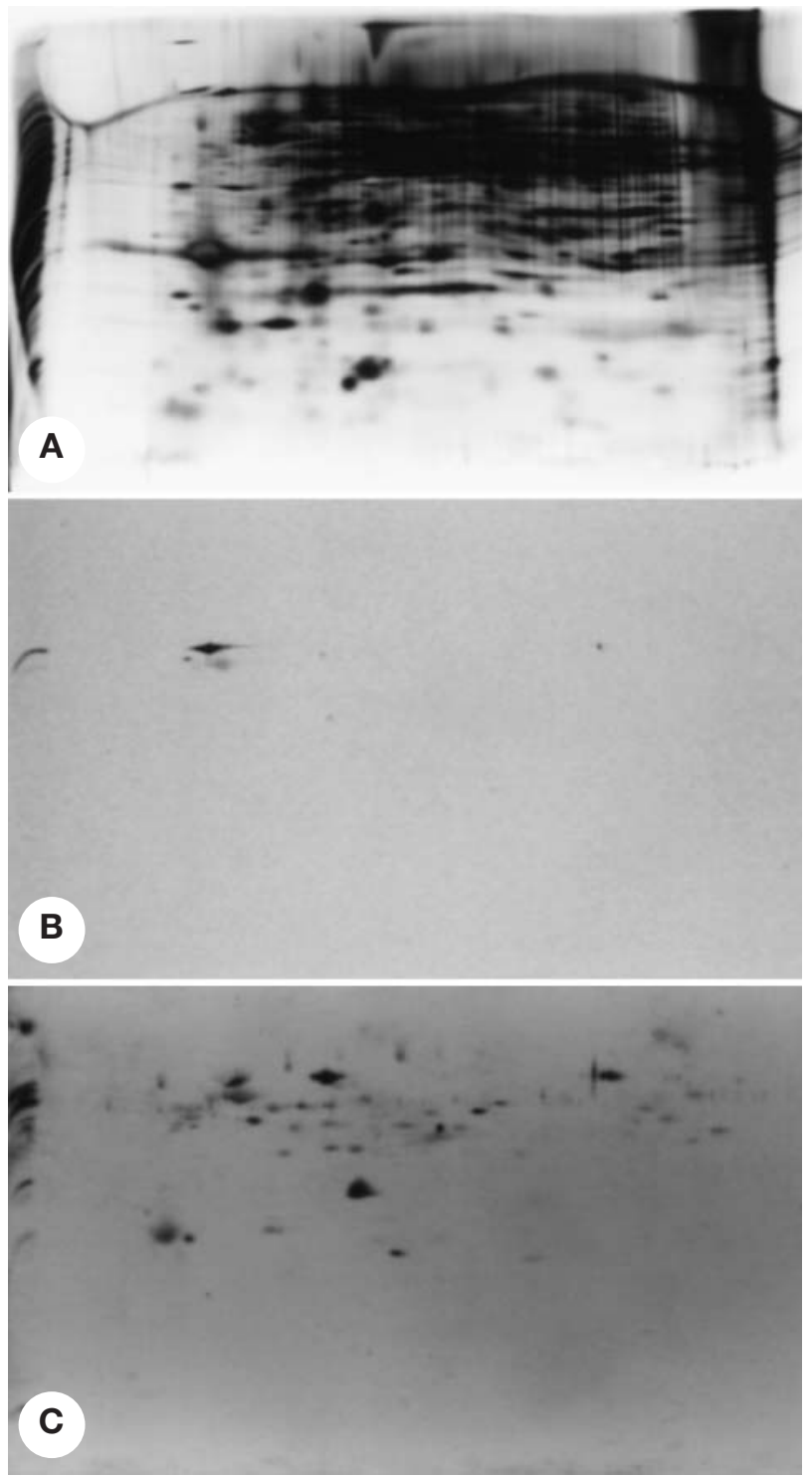

Fig. 1. Control whole-cell lysate of induced Escherichia coli XLOLR pBK-CMV separated by sodium dodecyl sulfate polyacrylamide gel electrophoresis (SDS-PAGE; left lane) and 2dimensional PAGE of: (A) total proteins in silver-stained gel; (B) antigenic proteins in Western blot probed with goat antiEdwardsiella ictaluri serum; (C) antigenic proteins in Western blot probed with convalescent catfish serum 


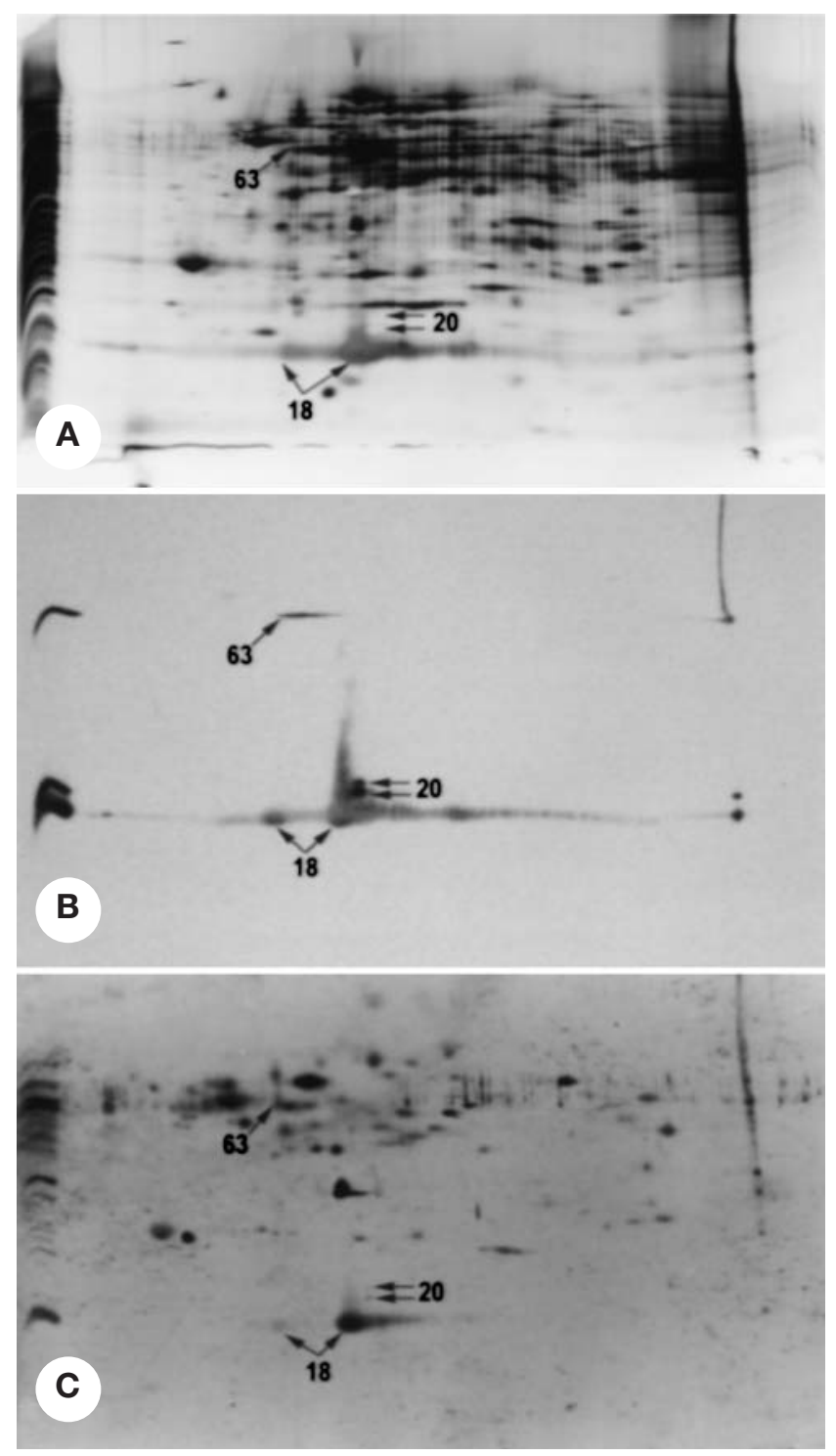

Fig. 2. Edwardsiella ictaluri. Whole-cell lysate of Induced Clone $4 \mathrm{~d} 6$ separated by sodium dodecyl sulfate polyacrylamide gel electrophoresis (SDS-PAGE; left lane) (A), (B) and (C) as in Fig. 1. The 63, 20 and $18 \mathrm{kDa}$ antigenic E. ictaluri proteins expressed by this clone are indicated

were strongly recognized in the control blot were not detected in the blot probed with SAG(4d6). The bands and spots no longer detected were a $63 \mathrm{kDa}$ band and corresponding spot, a $20 \mathrm{kDa}$ band corresponding spot and an $18 \mathrm{kDa}$ band and 2 corresponding spots. The pI values of the spots were all around 5.5 and their locations in the 2D-PAGE gel corresponded directly with molecular weights, pI values and migration patterns of cloned antigenic proteins expressed by Clone $4 \mathrm{~d} 6$ (Fig. 2A). These results indicated the proteins in the $E$. ictaluri WCL were the same as the cloned proteins in the $4 \mathrm{~d} 6$ WCL.

\section{Edwardsiella ictaluri DNA insert of Clone 4d6}

The molecular weight and pI of the putative protein encoded by each reading frame was determined using PC/Gene. The DNA sequence data showed that only 8 of the 11 possible open reading frames (ORFs) identified encoded proteins with molecular weights comparable to the expressed proteins. In addition, only 4 of the 8 had pI values comparable to the expressed proteins. The 4 ORFs were named eip55, eip20, eip19, and eip18 based on the molecular weights of the proteins they encoded (Fig. 4, Table 1). The eip55 was the only ORF identified in the insert that encoded a product large enough to compare to the $63 \mathrm{kDa}$-expressed antigenic protein. The eip18, eip19 and eip20 all encoded products with molecular weights and $\mathrm{pI}$ values comparable to the 18 and $20 \mathrm{kDa}$-expressed antigenic proteins. The eip20, eip55, and eip18 ORFs were all in the same

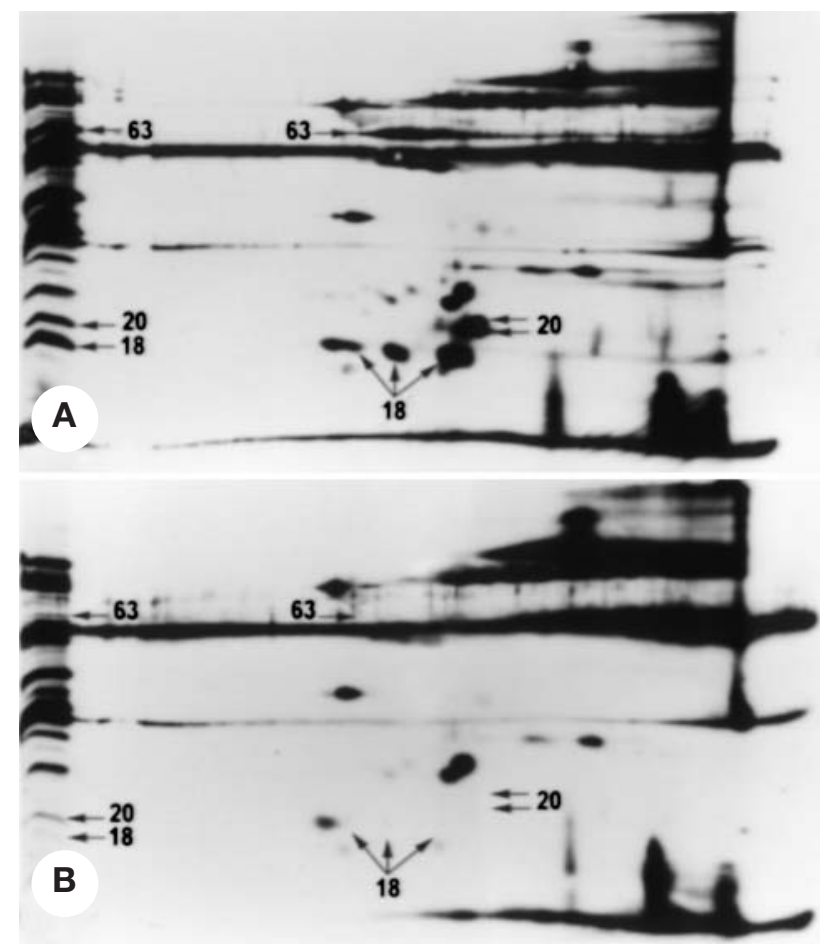

Fig. 3. Edwardsiella ictaluri. Whole-cell lysate (WCL) of separated by sodium dodecyl sulfate polyacrylamide gel electrophoresis (SDS-PAGE; left lane) and 2-dimensional PAGE antigenic proteins in Western blot probed with specific-clone adsorbed goat anti-ictaluri serum (SAG) adsorbed with WCL of control XLOLR pBK-CMV (A) and antigenic proteins in Western blot probed with SAG adsorbed with WCL of Clone 4d6 (B). The 63, 20 and $18 \mathrm{kDa}$ bands and proteins expressed by E. ictaluri and recognized by antibodies in SAG(pBK) but not SAG(4d6) are indicated 
reading frame in very close proximity in the insert. All 4 ORFs were encoded in the opposite direction of the vector promoter and putative promoter regions were identified manually for each of them based on the Escherichia coli $\sigma^{70}$ promoter consensus sequence (Snyder \& Champness 1997). This supported the data indicating that the proteins were being expressed from their own promoters rather than the IPTG-inducible promoter of the cloning vector.

Eip20, Eip55 and Eip19 had high identity to the Imp (impaired in nitrogen fixation) B, C, and F proteins of Rhizobium leguminosarum bv. trifolii, respectively (GenBank Accession No. AF361470: Table 2). In addition, the $3^{\prime}$ end of the $4 \mathrm{~d} 6$ clone encoded 162 amino acids that were similar to the amino terminus of the 594 amino acids of the ImpG protein, which was not detected on the blots. BLAST results further indicated that 2 ORFs located between the ORFs that were similar to impC and $i m p F$ had significant identity to other proteins in the NCBI data base. The first 150 of the 163 amino acids of the eip18-encoded protein, from bp 2806 to 2315 , has identity ranging from 25 to $32 \%$ for putative cytoplasmic/secreted proteins from a variety of bacteria, including Yersinia pestis, Pseudomonas aeruginosa, and Agrobacterium tumefaciens. The protein deduced from an ORF reading in the opposite direction of the imp-related related genes, from bp 974 to 2185 , has $30 \%$ identity and $45 \%$ similarity to a putative hemaglutinin related trans-membrane protein from Ralstonia solanacearum, and lesser identity to a variety of outer membrane proteins from $P$. putida, Rickettsia australis, Caulobacter crescentus, and Xyella fastidiosa. In addition to the similarity in amino acid sequence and gene arrangement to the Ralstonia leguminosarum imp locus, eip19, eip20, and eip55 had amino acid identity, ranging from 25 to $54 \%$, for a variety of hypothetical proteins from $R$. solanacearum, $P$. aeruginosa, A. tumefaciens, Y. pestis, and Salmonella typhimurium.

The PC/Gene analyses of deduced amino acid sequences of eip18, eip19, eip20 and eip55 characterized none of the 4 putative proteins as integral membrane proteins. The predicted folding type of eip55 was alpha helical $(\alpha)$, eip18 was beta pleated sheet $(\beta)$ and eip19 and eip20 were both a mix of alpha and beta folding $(\alpha / \beta)$. Amino acid sequences were analyzed for a variety of motifs using PC/Gene and GCG, with none being identified.
Association of insert ORFs with expressed proteins of Clone $4 \mathrm{~d} 6$

The deduced pI and molecular weight of the protein encoded by eip55, along with the approximated pI and molecular weight of the $63 \mathrm{kDa}$ protein expressed both by Edwardsiella ictaluri and the $4 \mathrm{~d} 6$ clone indicate that ORF eip55 encodes the $63 \mathrm{kDa}$-expressed protein (Table 1). The difference in the molecular weight calculated from the sequence and from the SDS-PAGE gels is attributable to the margin of error associated with both methods. Efforts to determine which ORF, eip18, eip19 or eip20, encodes the 18 and $20 \mathrm{kDa}$ expressed proteins were inconclusive. Both expressed proteins had approximated pI values that were comparable to the deduced pIs of the 3 ORFs (Table 1). Attempts to sequence the expressed proteins by automated N-terminal sequencing failed, apparently due to N-terminal blockage.

\section{Analysis of Clones 1.4, 5d2 and 5d3}

\section{Expressed Edwardsiella ictaluri proteins of Clones} $1.4,5 \mathrm{~d} 2$ and $5 \mathrm{~d} 3$

Silver-stained 2D-PAGE gels showed the expression of 3 unique proteins of 35, 33 and $27 \mathrm{kDa}$ in WCLs of Clones 1.4 and $5 \mathrm{~d} 2$ (Fig. 5A, Table 3), and unique pro-

Table 1. Edwardsiella ictaluri. Estimated molecular weights (MW) in kilodaltons and approximated isoelectric points (pI) of putative genes expressing antigenic proteins in the E. ictaluri insert of Clone $4 \mathrm{~d} 6$ compared with antigenic proteins expressed by Clone $4 \mathrm{~d} 6$ and the corresponding proteins expressed by E. ictaluri, as determined by antibody adsorption studies

\begin{tabular}{|c|c|c|c|c|c|c|}
\hline \multirow[t]{2}{*}{ Gene } & \multicolumn{2}{|c|}{ Encoded 4d6 } & \multicolumn{2}{|c|}{ Expressed 4d6 } & \multicolumn{2}{|c|}{ Expressed E. ictalur } \\
\hline & MW & $\mathrm{pI}$ & MW & $\mathrm{pI}$ & MW & $\mathrm{pI}$ \\
\hline eip55 & 54.5 & 4.85 & 63.0 & 5.5 & 63.0 & 5.5 \\
\hline eip20 & 19.5 & 5.09 & 20.0 & 5.5 & 20.0 & 5.5 \\
\hline eip19 & 18.8 & 4.78 & 18.0 & 5.5 & 18.0 & 5.5 \\
\hline eip18 & 17.8 & 4.96 & & & & \\
\hline
\end{tabular}



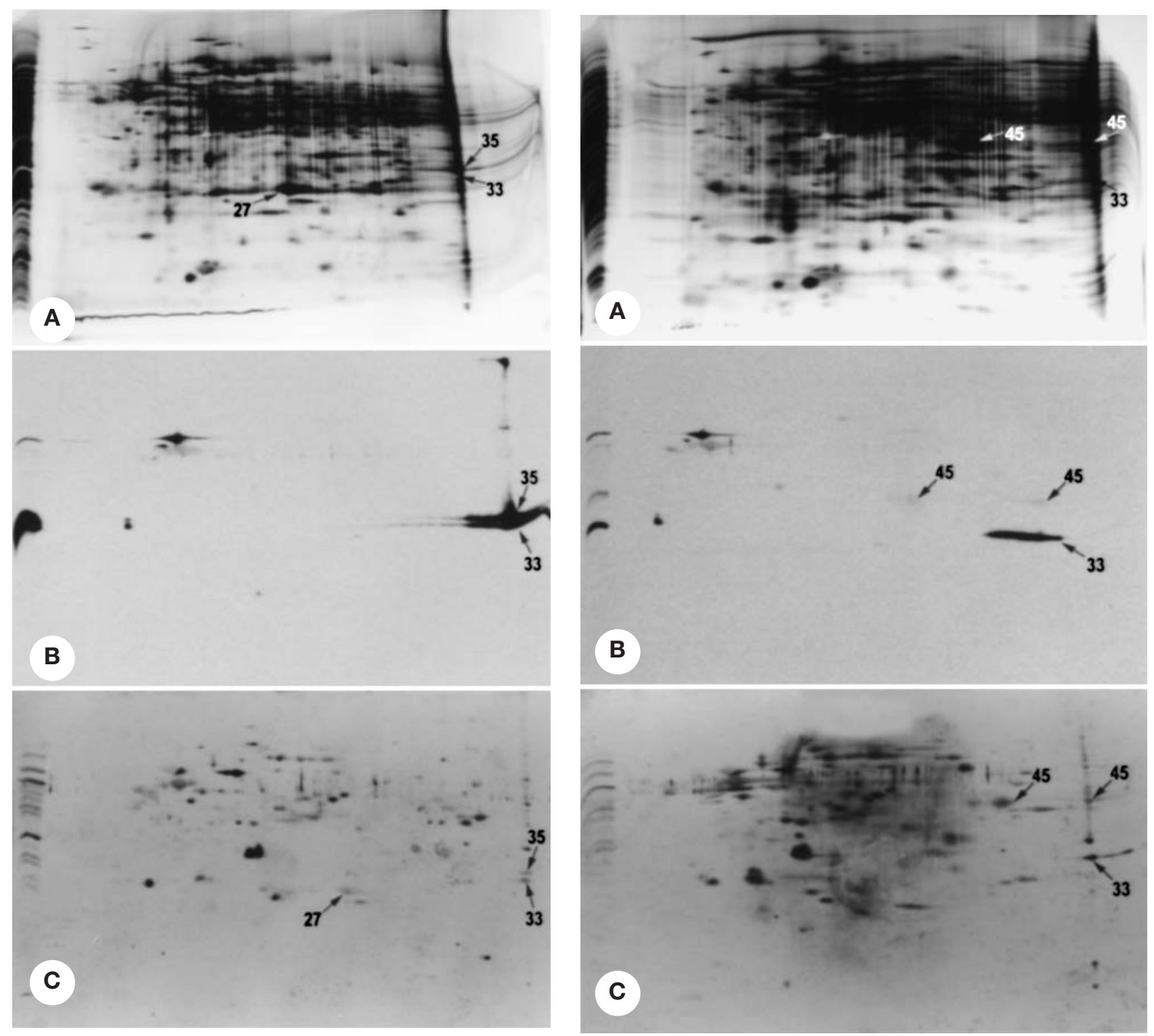

Fig. 5. Edwardsiella ictaluri. Whole-cell lysate of Induced Clone $5 \mathrm{~d} 2$ separated by sodium dodecyl sulfate polyacrylamide gel electrophoresis (SDS-PAGE; left lane). (A), (B) and (C) as in Fig. 1. The 27, 33 and $35 \mathrm{kDa}$ antigenic E. ictaluri proteins expressed by this clone are labeled; the $27 \mathrm{kDa}$ protein was not detected by the GAI

Table 2. Comparison of Edwardsiella ictaluri-encoded proteins with the Imp proteins of Rhizobium leguminosarum bv. trifolii (GenBank Accession No. AF361470). AA match: length of amino acid (AA) match/total length of Imp protein

\begin{tabular}{|lcccc|}
\hline $\begin{array}{l}\text { Rhizobium } \\
\text { proteins }\end{array}$ & $\begin{array}{c}\text { Similar E. ictaluri } \\
\text { ORFs }\end{array}$ & AA match & $\begin{array}{c}\% \\
\text { Identity }\end{array}$ & $\begin{array}{c}\% \\
\text { Similar }\end{array}$ \\
\hline ImpB & eip20 & $157 / 170$ & 54 & 71 \\
ImpC & eip55 & $475 / 495$ & 56 & 72 \\
ImpF & eip19 & $153 / 158$ & 44 & 47 \\
ImpG & Partial ORF & $148 / 161$ & 51 & 67 \\
\hline
\end{tabular}

Fig. 6. Whole-cell lysate of Induced Clone $5 \mathrm{~d} 3$ separated by sodium dodecyl sulfate polyacrylamide gel electrophoresis (SDS-PAGE; left lane). (A), (B) and (C) as in Fig.1. The 45, 45 and $33 \mathrm{kDa}$ antigenic E. ictaluri proteins expressed by this clone are indicated (the $45 \mathrm{kDa}$ protein ran as 2 isoelectric isomers

teins of 45 and $33 \mathrm{kDa}$ in the WCL of Clone $5 \mathrm{~d} 3$ (Fig. 6A, Table 3) compared to WCL of the pBK control (Fig. 2). In WCLs of 1.4 and $5 \mathrm{~d} 2$, the $27 \mathrm{kDa}$ protein ran as a large, elongated black spot with an approximated pI of 5.2, and the $35 \mathrm{kDa}$ protein ran as an elongated black spot. In all 3 clones, the $33 \mathrm{kDa}$ protein ran as an elongated yellow spot. The $45 \mathrm{kDa}$ protein expressed by Clone $5 \mathrm{~d} 3 \mathrm{ran}$ as 2 isoelectric isomers visualized as round, dark spots. The approximated pI of the 2 isomers were 5.9 and 6.6 respectively. The 35 and $33 \mathrm{kDa}$ spots were difficult to identify in silver stains because 
Table 3. Comparison of proteins encoded and expressed by Edwardsiella ictaluri clones and Escherichia coli. Encoded proteins are deduced molecular weights (MW) in kilodaltons and isoelectric points (pI) of putative antigenic protein genes encoded by the E. ictaluri inserts of Clones 1.4, $5 \mathrm{~d} 2$ and $5 \mathrm{~d} 3$ compared with homologous genes encoded by E. coli. Expressed proteins are the estimated MW and pI of antigenic proteins expressed by Clones 1.4, $5 \mathrm{~d} 2$ and $5 \mathrm{~d} 3$, and corresponding proteins expressed by $E$. coli. Values reported for E. coli were obtained using the Swiss 2D-service, unless denoted with a numerical superscript and corresponding reference. No values are given for proteins that were not encoded or expressed. nd: not determined

\begin{tabular}{|c|c|c|c|c|c|c|c|c|c|c|c|c|c|c|c|c|}
\hline \multirow{3}{*}{ Gene } & \multicolumn{8}{|c|}{ Encoded } & \multicolumn{8}{|c|}{ - Expressed } \\
\hline & \multicolumn{2}{|c|}{1.4} & \multicolumn{2}{|c|}{$5 \mathrm{~d} 2$} & \multicolumn{2}{|c|}{$5 \mathrm{~d} 3$} & \multicolumn{2}{|c|}{ E. coli } & \multicolumn{2}{|c|}{1.4} & \multicolumn{2}{|c|}{$5 \mathrm{~d} 2$} & \multicolumn{2}{|c|}{$5 \mathrm{~d} 3$} & \multicolumn{2}{|c|}{ E. coli } \\
\hline & MW & pI & MW & pI & MW & $\mathrm{pI}$ & MW & $\mathrm{pI}$ & MW & pI & MW & $\mathrm{pI}$ & MW & pI & MW & pI \\
\hline rpiA & 22.8 & 5.20 & 22.8 & 5.20 & - & - & 22.9 & 5.20 & 27.0 & 5.7 & 27.0 & 5.7 & - & - & $\begin{array}{l}25.9 \\
27.0^{\mathrm{a}}\end{array}$ & $\begin{array}{c}5.06 \\
-\end{array}$ \\
\hline iciA & 33.3 & 7.69 & 33.3 & 7.69 & - & - & 33.5 & 6.40 & 35.0 & $\geq 6.6$ & 35.0 & $\geq 6.6$ & - & - & nd & nd \\
\hline$y g g E$ & 26.0 & 7.65 & 26.0 & 7.65 & 26.0 & 7.65 & 26.6 & 6.10 & 33.0 & $\geq 6.6$ & 33.0 & $\geq 6.6$ & 33.0 & $\geq 6.6$ & nd & nd \\
\hline$y g g B$ & $11.2^{\mathrm{b}}$ & 4.23 & - & - & 30.6 & 9.04 & 30.9 & 7.90 & - & - & - & - & - & - & nd & nd \\
\hline fda & - & - & - & - & 39.2 & 5.35 & 39.0 & 5.52 & - & - & - & - & $\begin{array}{l}45.0 \\
45.0\end{array}$ & $\begin{array}{l}5.9 \\
6.6\end{array}$ & $\begin{array}{l}39.8 \\
40.7 \\
42.0^{\mathrm{c}}\end{array}$ & $\begin{array}{c}5.55 \\
5.43 \\
-\end{array}$ \\
\hline ORF_x & - & - & - & - & - & - & - & - & - & - & 16.0 & nd & 19.0 & nd & - & - \\
\hline
\end{tabular}

they ran at the edge of the gel, where the pH gradient was approximately 6.6. This area of the gel had a number of proteins that appeared to have only partially entered into the first-dimension isoelectric focusing (IEF) tube gel. Two proteins of 16 and $19 \mathrm{kDa}$, seen in SDS-PAGE gels of $5 \mathrm{~d} 2$ and $5 \mathrm{~d} 3$ WCLs respectively (data not shown), could not be detected in the 2DPAGE gels. The locations of the 35 and $33 \mathrm{kDa}$ proteins and the absence of the 16 and $19 \mathrm{kDa}$ proteins from the 2D-PAGE gels may indicate that their pI values are outside the range of the $\mathrm{pH}$ gradient used in the IEF tube gels. In 2D-PAGE Western blots probed with GAI, the $27 \mathrm{kDa}$ protein was not detected, the 35 and $33 \mathrm{kDa}$ protein spots were detected strongly and the $45 \mathrm{kDa}$ spot was detected faintly. All 4 proteins were detected faintly in 2D-PAGE Western blots probed with CCS (Figs. $5 \& 6$ ), which indicates they are expressed during an infection.

Relatedness of the proteins expressed by Clones 1.4, $5 \mathrm{~d} 2$, and $5 \mathrm{~d} 3$

Comparisons of molecular weight, isoelectric point, size, shape and staining characteristics of the expressed proteins indicated that the 3 clones were expressing some of the same proteins (Table 3; Figs. 5 \& 6). Replicate SDS-PAGE Western blots, with WCLs of pBK and Clones 1.4, 5d2, and $5 \mathrm{~d} 3$ loaded in the sample lanes, were probed with SAG(pBK), SAG(1.4), SAG(5d2) and SAG(5d3). The results (Table 4) showed the $35 \mathrm{kDa}$ protein in WCLs of Clones 1.4 and $5 \mathrm{~d} 2$ was adsorbed out with either SAG(1.4) or SAG(5d2), indicating that the protein was the same in both clones.
The $33 \mathrm{kDa}$ protein in WCLs of all 3 clones was either fully or partially adsorbed by SAG(1.4), SAG(5d2) or $\mathrm{SAG}(5 \mathrm{~d} 3)$, indicating that the $33 \mathrm{kDa}$ protein was the same protein expressed in all 3 clones. The relationship of the $27 \mathrm{kDa}$ protein expressed by clones 1.4 and $5 \mathrm{~d} 2$ was not determined because this protein was only recognized by the CCS.

\section{Edwardsiella ictaluri DNA inserts of Clones 1.4, 5d2 and 5d3}

The sequence of the overlapping Edwardsiella ictaluri genomic inserts of $5 \mathrm{~d} 2$ and $5 \mathrm{~d} 3$, and the T3 and T7 sequence data of the 1.4 insert are deposited in

Table 4. Edwardsiella ictaluri. Recognition of antigenic proteins expressed by Clones 1.4, 5d2 and 5d3 in SDS-PAGE Western blots probed with specific-clone adsorbed goat anti-E. ictaluri (SAG) serum. Molecular weight (MW) units are kDa. ++: strong recognition, +: faint recognition; -: no recognition

\begin{tabular}{|cccccc|}
\hline \multirow{6}{*}{ Clone } & $\begin{array}{c}\text { Protein } \\
\end{array}$ & MW & SAG & \multicolumn{4}{c|}{ Antiserum } \\
& & SAG & SAG & SAG \\
& & $(1.4)$ & $(5 \mathrm{~d} 2)$ & $(5 \mathrm{~d} 3)$ \\
\hline \multirow{2}{*}{1.4} & 33 & ++ & - & - & + \\
& 35 & ++ & - & - & + \\
$5 \mathrm{~d} 2$ & 33 & ++ & - & - & + \\
& 35 & ++ & - & - & + \\
& 16 & ++ & ++ & + & ++ \\
$5 \mathrm{~d} 3$ & 45 & ++ & ++ & ++ & - \\
& 33 & ++ & - & - & - \\
& 19 & ++ & ++ & ++ & + \\
& & + & & & \\
\hline
\end{tabular}



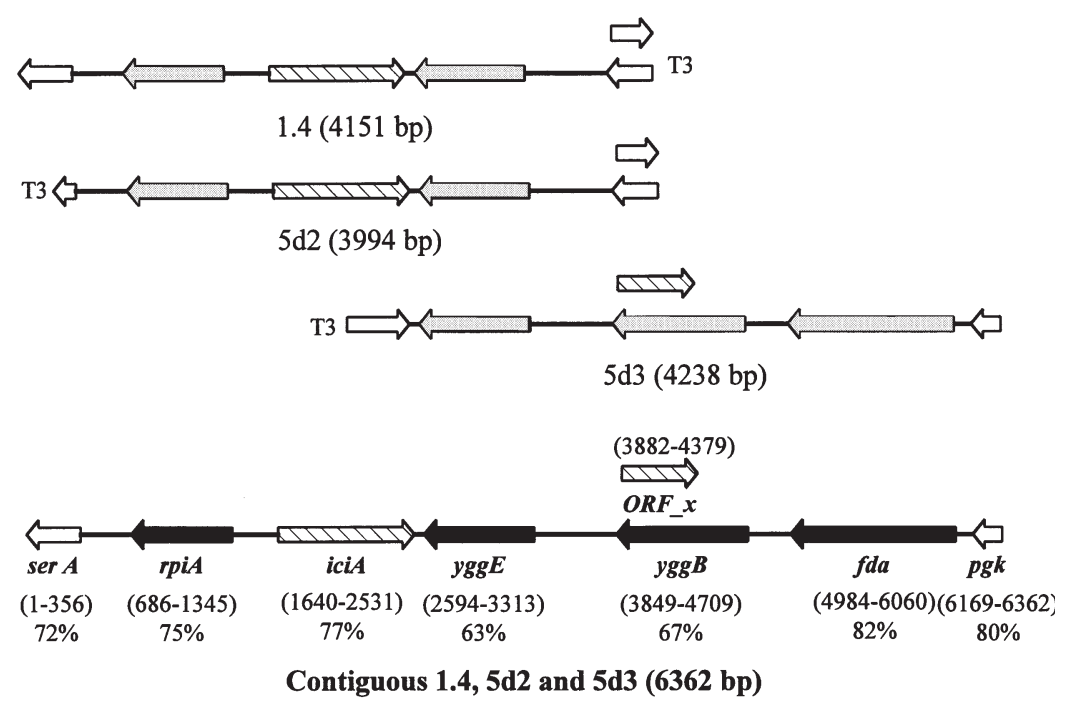

Fig. 7. Edwardsiella ictaluri. Schematic diagram of the overlapping inserts and contiguous sequence of genomic inserts in Clones 1.4, $5 \mathrm{~d} 2$ and $5 \mathrm{~d} 3$. The open reading frames (ORF) of putative gene regions are denoted by arrows in the direction they are encoded, and the names and percent nucleic acid identity with Escherichia coli are shown under the inserts. Open arrows indicate partial reading frames. Orientation of the insert in cloning vector is designated by T3

reading frames of $5 \mathrm{~d} 23$ sequence, many of which were overlapping. BLAST results showed that 5 complete ORFs had high identity to E. coli rpiA, iciA, $y g g E, y g g B$ and $f d a$, and 2 partial ORFs had high identities to partial sequences of serA and pgk genes. A comparison of the regions encoding the $E$. coli genes with the putative E. ictaluri genes is presented in Table 5. Based on the $E$. coli $\sigma^{70}$ promoter consensus sequence (Snyder \& Champness 1997), putative promoter regions were identified manually for 6 of the 7 ORFs in the E. ictaluri $5 \mathrm{~d} 23$ sequence. The promoter region for the pgk gene homolog, as well as most of the 5' end of the gene were not included in the insert. A promoter region could be identified for $\operatorname{ser} A$, but most of the $3^{\prime}$ end of the gene was absent from the insert.

The serA gene encodes D-3-phosphoglycerate dehydrogenase (PDGH; Accession No. P08328), rpiA encodes ribose 5-phosphate isomerase A (RPIA; Hove-Jensen \& Maigaard 1993, Acces-

GenBank under Accession No. AF037440. The complete region encoded by the 3 inserts, designated as $5 d 23$, was 6362 bp with a GC content of $58 \%$. Clones 1.4 and $5 \mathrm{~d} 2$ contained the same inserts, except that the insert in 1.4 was $207 \mathrm{bp}$ larger at the T7 end and the inserts were in opposite orientations relative to the pBK-CMV promoter. The sequence data showed that the insert of $5 \mathrm{~d} 3$ overlapped with the inserts of 1.4 and $5 d 2$ by 2027 bp (Fig. 7).

Sequence comparison using BLAST showed that the $6362 \mathrm{bp} 5 \mathrm{~d} 23$ sequence of Edwardsiella ictaluri had a large region of similarity to the Escherichia coli genome in the 65 to $68 \mathrm{~min}$ region (Accession No. U28377): 19 potential ORFs were identified in the 6

Table 5. Comparison of nucleic acid (NA) and amino acid (AA) percent sequence identity and similarity between Escherichia coli genes and their Edwardsiella ictaluri homologs encoded by the $5 \mathrm{~d} 23$ sequence. p: partial genes

\begin{tabular}{|lccccc|}
\hline Gene & $\begin{array}{c}\% \text { NA } \\
\text { identity }\end{array}$ & Gaps & $\begin{array}{c}\% \text { AA } \\
\text { identity }\end{array}$ & $\begin{array}{c}\text { \% AA } \\
\text { similarity }\end{array}$ & Gaps \\
\hline serA $(p)$ & 71.9 & 0 & 78.6 & 88.0 & 0 \\
rpiA & 75.0 & 0 & 83.6 & 88.6 & 0 \\
iciA & 76.8 & 0 & 85.8 & 91.2 & 0 \\
$\operatorname{yggE}$ & 63.2 & 4 & 63.0 & 76.0 & 3 \\
$\operatorname{yggB}$ & 66.8 & 0 & 64.0 & 66.8 & 0 \\
fda & 82.1 & 1 & 87.7 & 91.3 & 1 \\
$\operatorname{pgk}(p)$ & 80.0 & 0 & 92.1 & 93.7 & 0 \\
& & & & & \\
\hline
\end{tabular}

sion No. P27252), iciA encodes a specific inhibitor of chromosomal initiation of replication (ICIA; Thoney et al. 1991, Accession No. P24194), yggE encodes the hypothetical YGGE protein (Accession No. P11668), $y g g B$ encodes $Y G G B$, a protein involved in responses to osmotic stress (Levina et al. 1999, Accession No. P11666), fda encodes fructose 1,6-bisphosphate aldolase (aldolase; Alefounder et al. 1989, Accession No. P11604), and pgk encodes phosphoglycerate kinase (PGK Accession No. P11665). Edwardsiella ictaluri encoded fda also had high similarities with the aldolase genes of Haemophilus influenza (Fleischmann et al. 1995), Euglena gracilus (Accession No. X89769), Neurospora crassa (Accession No. L42380), Schizosaccharomyces pombe (Mutoh \& Hayashi 1994), and Saccharomyces cerevisiae (Schwelberger et al. 1989), with identities of $63,59.9,40.6,59.2$ and $56.1 \%$ respectively. The E. ictaluri encoded iciA also had $61.0 \%$ identity to the iciA gene of Aeromonas salmonicida (Accession No. ASU65741).

DNA sequence data showed the inserts of Clones 1.4 and $5 \mathrm{~d} 2$ both encoded partial ORFs for serA and $y g g B$, and complete ORFs for rpiA, iciA and $y g g E$. The insert of $5 \mathrm{~d} 3$ encoded partial ORFs for iciA and $p g k$, and complete ORFs for $y g g E, y g g B$ and fda (Fig. 7). The partial ser $A$ in the inserts of 1.4 and $5 \mathrm{~d} 2$ encoded a partial protein that was considered to be too small (6.4 kDa) for further consideration. The partial $y g g B$ in the insert of $5 \mathrm{~d} 2$ could not be transcribed because it 
lacked the promoter and $5^{\prime}$ region of the gene, but the partial $y g g B$ in the insert of 1.4 could be transcribed since it was in frame with the pBK-CMV promoter, encoding a $302 \mathrm{bp}$ fusion protein with a deduced size of $11.2 \mathrm{kDa}$ and $\mathrm{pI}$ of 4.23 . The partial iciA encoded by the insert of $5 \mathrm{~d} 3$ could not be transcribed since it lacked the promoter and 5 ' region of the gene and was out of frame with the pBK-CMV promoter. Proteins that each of the 3 inserts could theoretically express based on whether the genes could be transcribed are shown in Table 3.

The PC/Gene analysis of deduced amino acid sequences of RPIA, ICIA, and aldolase characterized the 3 proteins as non-integral with $\alpha / \beta$ folding. The YGGE protein was characterized as non-integral, with $\alpha / \beta$ folding and a potential cleavage site for a secretory signal between amino acids 23 and 24. The YGGB protein was characterized as an integral membrane protein, with 3 transmembrane domains and $\alpha / \beta$ folding. The ICIA protein and aldolase both have characteristic signatures in their amino acid sequences. The ICIA protein is in the LysR subfamily (Henikoff et al. 1988), and the LysR signature was identified from amino acid residue 15 to 51 in the amino acid sequence of Edwardsiella ictaluri ICIA. The Class II aldolase zinc-binding signature (Berry \& Marshall 1993) was identified from residue 94-116 in the amino acid sequence of E. ictaluri aldolase, with histidine residues located at Positions 107 and 110. The aldolase acidic signature was located from Residues 166 to 187.

Association of insert ORFs with expressed proteins of Clones $1.4,5 \mathrm{~d} 2$, and $5 \mathrm{~d} 3$

Comparison between the Western blots, the analysis of the deduced amino acid sequence, and deduced protein structure supports the consensus 5d23 map presented in Fig. 7. The $27 \mathrm{kDa}$ antigenic protein expressed by 1.4 and $5 \mathrm{~d} 2$ is putatively identified as RPIA, and the $35 \mathrm{kDa}$ antigenic protein expressed by 1.4 and $5 \mathrm{~d} 2$ is putatively identified as ICIA. The $33 \mathrm{kDa}$ protein expressed by all 3 clones is the putative YGGE protein. Based on molecular weight, pI and the separation into 2 isoelectric isomeric spots in 2D-PAGE gels, the results further suggest that the $45 \mathrm{kDa}$ antigenic protein expressed by $5 \mathrm{~d} 3$ is aldolase. The hypothetical YGGB protein did not appear to be expressed by Clone 5d3. However, a possible ORF, designated ORF_x, was identified in the opposite orientation within the $y g g B$ ORF. This was the only ORF large enough to encode the $19 \mathrm{kDa}$ antigenic protein expressed by Clone $5 \mathrm{~d} 3$, with a predicted size of $18.3 \mathrm{kDa}$ and predicted $\mathrm{pI}$ of 7.04. The $\mathrm{pI}$ value was outside the $\mathrm{pH}$ range of the IEF gel, which could explain why the protein was only seen in SDS-PAGE gels. A truncated version of ORF_x in Clone $5 \mathrm{~d} 2$ may correspond to the $16 \mathrm{kDa}$ antigenic protein of Clone $5 \mathrm{~d} 2$. Antibody adsorption analysis failed to clarify the relatedness of the 19 and $16 \mathrm{kDa}$ proteins.

\section{Vaccine trial}

Catfish feeding activity remained normal and there were no mortalities following the vaccination or boost. Mortalities that occurred following challenge all cultured positive for Edwardsiella ictaluri and had internal or external lesions consistent with acute ESC. Mortalities occurred from Days 6 to 16 post-challenge, peaking at Day 11 with 16 mortalities. Results showed that, compared to the challenged saline control treatment, mortality was significantly lower in all the vaccine-treatment groups (Table 6), including the Escherichia coli control. Percent mortality was not significantly different between any vaccine treatment groups, although RPS was lowest in the treatment group vaccinated with E. ictaluri (BHI) WCL and highest in the treatment group vaccinated with pBK WCL, the control cloning vector without $E$. ictaluri insert.

\section{DISCUSSION}

Characterization of antigens expressed during the course of an infection by Edwardsiella ictaluri may facilitate the development of an optimal ESC vaccine and aid in the elucidation of bacterial mechanisms of pathogenesis. In this study, antibody screening of an $E$. ictaluri genomic library was successfully used to generate a pool of 32 clones expressing antigenic $E$. ictaluri proteins produced during an infection. Characterization of the antigens encoded by 4 of these clones

Table 6. Ictalurus punctatus. Results of catfish vaccination and challenge. One saline-vaccinated control treatment was not challenged (nc) with Edwardsiella ictaluri. Percent mortality is mean $\pm \mathrm{SE}$ of 3 replicate tanks; means with the same letters are not significantly different. Relative percent survival (RPS) is $100 \times\{1-(\%$ mortality vaccinated $\div \%$ mortality controls $)\}$

\begin{tabular}{|lcc|}
\hline Treatment & \% Mortality & RPS \\
\hline Saline, nc & $0 \quad \mathrm{C}$ & - \\
Saline & $87.9 \pm 8.02 \mathrm{~A}$ & - \\
E. ictaluri (BHI) & $37.0 \pm 17.9 \mathrm{~B}$ & 57.9 \\
E. ictaluri (MM19) & $19.1 \pm 6.05 \mathrm{BC}$ & 78.3 \\
pBK & $9.1 \pm 0.00 \mathrm{BC}$ & 89.7 \\
$4 \mathrm{~d} 6$ & $27.3 \pm 5.24 \mathrm{BC}$ & 69.0 \\
$5 \mathrm{~d} 2$ & $32.7 \pm 9.29 \mathrm{~B}$ & 62.8 \\
$5 \mathrm{~d} 3$ & $25.9 \pm 7.40 \mathrm{BC}$ & 70.5 \\
\hline
\end{tabular}


is reported here. The associations between the putative ORFs and expressed proteins identified here are hypothesized based on indirect evidence, including deduced and actual molecular weights and pIs. Amino acid sequencing of expressed cloned proteins or data from adsorbtion studies using subclones containing single genes are needed to confirm these associations.

The 18682 bp imp locus of Rhizobium leguminosarum contains $14 \mathrm{imp}$ genes, A to $\mathrm{N}$, and encodes proteins involved in a putative temperature-dependent protein secretion system (GenBank Accession No. AF361470). The 4 proteins encoded in clone $4 \mathrm{~d} 6$ are essentially similar over the entire length of each reading frame, or in the case of impG, the amino terminus, and are arranged in the same order and direction. In $R$. leguminosarum, impD and impE are found between $i m p C$ and $i m p F$, and are 1389 and 831 bp, respectively. The 2 ORFs in the same location in Clone 4d6, eip18 and the hypothetical membrane protein, are only 492 and $831 \mathrm{bp}$, respectively, indicating some divergence in the locus. The antibody response of channel catfish to eip55 and eip18 would indicate that they are either surface proteins or are secreted during the infection, which is consistent with the putative role of the similar Imp proteins in protein secretion. Eip18, however, also had similarity to SciM (149 of 161 amino acids; 32\% identity, $54 \%$ similarity), a putative cytoplasmic protein encoded in a large locus associated with fimbriae production in Salmonella enterica (Folkesson et al. 1999). Further sequencing and gene-deletion studies are required to further evaluate the role of these proteins in infection and immunity.

The overlapping inserts of Clones 1.4, $5 \mathrm{~d} 2$ and $5 \mathrm{~d} 3$ had strong similarity with the 65 to $68 \mathrm{~min}$ region of the Escherichia coli genome (Accession No. U28377). The Edwardsiella ictaluri inserts encoded homologs of the E. coli genes serA (partial), rpiA, iciA, yggE, yggB, fda, and $p g k$ (partial). The E. ictaluri region of the genome differed from E. coli in that it lacked a large segment including sbm, ygfD, ORF_o275, ORF_0492, and ORF_f303 located between iciA and $y g g E$, as well as $y g g A$, located between $y g g E$ and $y g g B$ in $E$. coli. The hypothesized E. ictaluri rpiA, iciA, yggE and $f d a$ homologs are all expressed during an infection and are antigenic to catfish.

The close proximity of rpiA, $f d a$, and pgk in the genome may be related to the functional roles of the enzymes they encode. Glycolysis is the breakdown of glucose to generate metabolic energy in the form of ATP. Aldolase and PGK are both enzymes in the glycolysis pathway, which occurs in the cell cytosol. In the non-oxidative branch of the pentose phosphate pathway, which is also cytosolic, RPIA catalyzes the first reaction in the path that ultimately converts ribose 5phosphate to fructose 6-phosphate and glyceraldehyde 3-phosphate, both of which are intermediates in the glycolysis pathway (Stryer 1988).

The ICIA protein belongs to the LysR family of prokaryotic regulators which act as transcriptional activators, and can also regulate their own expression. These proteins, including the Edwardsiella ictaluri ICIA, are identified by a helix-turn-helix signature motif located in their N-terminal domain. In Escherichia coli, the ICIA protein is a homodimer that binds to three 13-mers in the origin (oriC) to block initiation of replication by the dnaA initiatior protein (Thoney et al. 1991).

The $33 \mathrm{kDa}$ YGGE protein was the only protein encoded and expressed by all 3 clones (Table 3). Although the molecular weight of the actual expressed Escherichia coli YGGE has not been determined, the deduced molecular weight and pI of the protein encoded by $y g g E$ are comparable between Edwardsiella ictaluri and E. coli (Table 3). The putative YGGE protein of E. ictaluri was characterized as a non-integral membrane protein with a possible secretory signal and $\alpha / \beta$ folding. The identification of a putative secretory signal suggests that YGGE may be an extracellular protein.

The fructose 1,6-bisphosphate aldolases are divided into 2 classes based on their molecular and catalytic properties. Class I aldolases are found in animals, plants and green algae. Class II aldolases occur in eukaryotic fungi and green algae and prokaryotic bacteria and blue-green algae (Baldwin et al. 1978). Class II aldolases are normally homodimers with a subunit molecular weight of 30 to $40 \mathrm{kDa}$. They are strongly inhibited by metal-chelating agents such as EDTA, since a divalent metal cation is required for the formation of the active metalloprotein complex (Stribling \& Perham 1973). Class II aldolase appears to be highly conserved among prokaryotes, fungi and blue-green algae (Alefounder et al. 1989). Although the highest sequence identity was with the fda of Escherichia coli, cloned Edwardsiella ictaluri fda also had high sequence identities with a number of other organisms including bacteria, blue-green algae, and fungi. Class II aldolases are identified by a signature motif consisting of 2 conserved regions, which were present in the E. ictaluri aldolase.

The YGGB protein is involved in the response to osmotic stress in Escherichia coli, although an actual expressed protein has not yet been identified. The activity of YGGB in E. coli was demonstrated using yggB deletion mutants and patch-clamp analysis (Levina et al. 1999). The YGGB encoded by the Edwardsiella ictaluri insert was either not expressed, not antigenic, or not detectable by the methods used in this study. Since the computed pI value was out of range of the first-dimension IEF tube gels, the protein may not 
have run in the 2D-PAGE gel. Alternatively, the results may indicate that expression of YGGB is somehow regulated. Two antigenic proteins of 16 and $19 \mathrm{kDa}$ expressed by clones $5 \mathrm{~d} 2$ and $5 \mathrm{~d} 3$, respectively, could not be associated with any of the identified E. coli homologs. A putative ORF_x, was identified in the opposite direction within the $y g g B$ ORF, which may account for these proteins.

Specific-clone adsorbed GAI was used to further determine the relatedness of cloned proteins to proteins expressed by Edwardsiella ictaluri cells. This approach succeeded with Clone $4 \mathrm{~d} 6$, but not with clones $1.4,5 \mathrm{~d} 2$, or $5 \mathrm{~d} 3$. This is most probably due to the level of expression of the products of those genes in $E$. ictaluri: 3 of the genes encode enzymes involved in glycolysis, and their products would not be expected to be present in high copy number, and copy number would depend on the growth conditions at the time the cells were harvested. As a regulatory protein, ICIA would also be present in low concentrations. Finally, sequence analysis of the YGGE protein indicated that it is probably extracellular and would have been lost in the production of the E. ictaluri WCL because the cells were washed prior to lysis. In contrast, the cloned genes were present on multicopy plasmids in Escherichia coli, which would increase expression of the products. In addition, any proteins regulating their expression would not be present unless $E$. coli encoded and was expressing similar ones, which could again result in an increased concentration. Both of these conditions could explain the detection of these proteins in E. coli and the lack of their detection in E. ictaluri.

The library was originally screened with GAI because quantities of CCS were limited and large quantities of serum were required for the screening. The CCS was used to confirm that selected clones were expressing Edwardsiella ictaluri proteins expressed in the catfish during infection. If sufficient quantities of CCS had been available, it would have been preferable to use CCS rather then GAI for the initial library screening. The direct use of CCS might have resulted in the identification of additional antigenic proteins that were preferentially recognized by the catfish immune system.

Results of the vaccine study were inconclusive due to the apparent cross-reactive protection of the Escherichia coli host strain. The high level of protection of $E$. coli was unexpected, but not unprecedented. Although all bacterial species possess unique proteins, a large number of proteins are shared among species (Kaufmann 1993). The E. coli host strains used in this study were found to share a large number of cross-reactive proteins with Edwardsiella ictaluri. The catfish antiserum was adsorbed with E. ictaluri LPS prior to use, so the observed cross-reactive antibodies were against proteins rather than a conserved LPS antigen. The normal catfish serum used as a control had no antibodies against $E$. ictaluri, indicating that the cross-reactive antibodies present in the CCS serum were the result of exposure to E. ictaluri. Previous studies have shown both high cross-reactivity of catfish E. ictaluri antibodies against $E$. coli and protection from E. ictaluri challenge following vaccination with $E$. coli (Tyler \& Klesius $1994 \mathrm{a}, \mathrm{b})$. Those studies used Strain J5, a rough mutant of $E$. coli, and the cross-reactivity was assumed to be between a conserved LPS core antigen because antibody adsorbtion with Salmonella typhimurium LPS core antigen decreased cross-reactive ELISA titers (Tyler \& Klesius 1994b).

Subsequent to the vaccine trials, the DNA-sequencing and protein-expression analysis revealed that each of the clones had Edwardsiella ictaluri inserts large enough to encode several proteins, and none of the cloned antigenic proteins were under control of the IPTG-inducible promoter of the vector. The cloned $E$. ictaluri proteins were expressed because the Escherichia coli RNA polymerase was able to recognize $E$. ictaluri transcriptional promoters. Because transcription of the cloned proteins was regulated by E. ictaluri promoters rather than the strong, inducible vector promoter, the concentrations of cloned proteins were lower than expected for an expression vector. This may have resulted in levels of expressed cloned proteins that were too low for the WCLs to serve as subunit vaccines. The genes encoded by E. ictaluri inserts will need to be subcloned in the same reading frame as the vector's inducible promoter to correct this problem. Overexpression of the cloned proteins may allow differences in protective capabilities of the proteins to be measured. Alternatively, since the pBK-CMV vector is also designed to express cloned inserts under control of the eukaryotic cytomegalovirus (CMV) promoter, protective capabilities of sub-cloned antigenic $E$. ictaluri proteins could be assessed using DNA vaccination.

This study has resulted in the putative identification and characterization of a number of antigenic Edwardsiella ictaluri proteins expressed and recognized by the catfish immune system during an infection. To our knowledge, this is the first report of the cloning of genes of E. ictaluri antigenic proteins, and it represents the first attempt to identify antigenic E. ictaluri antigens by more than their molecular weight or location in the cell. The antigenic E. ictaluri proteins that were putatively identified are enzymes and transcriptional regulators. The fact that these proteins are associated with housekeeping functions, as opposed to virulence factors, does not preclude them from being protective antigens. Protective T-cell responses against crossreactive bacterial antigens have been observed fre- 
quently in mammals. These cross-reactive antigens are conserved proteins shared by a number of bacteria (Kaufmann 1993). Based on the high antibody crossreactivity and conservation of the proteins between Escherichia coli and E. ictaluri, as well as other bacteria, it is possible some of the putatively identified cloned E. ictaluri proteins are T-cell antigens. The identification of potential protective $\mathrm{T}$ cell antigens may be required for the development of a successful ESC vaccine, since a cell-mediated immune response appears to be a necessary component of the catfish protective immune response against $E$. ictaluri (Thune et al. 1997a).

Cloning and characterization of antigens recognized by the host immune response during an infection can provide insight into which pathogen components are important in eliciting protective immunity. The antigenic proteins identified in this study may be candidates for insertion and expression in the attenuated, thymidine-kinase deficient channel catfish virus (CCV) vector, produced by Zhang \& Hanson (1995, 1996). Alternatively, over expression of important protective antigens in live attenuated Edwardsiella ictaluri vaccines may enhance their efficacy. Additionally, the protective capabilities of Escherichia coli due to cross-reactive antigens suggests cross-reactive vaccination may provide another vaccine strategy to investigate in developing a successful ESC vaccine.

Acknowledgements. We thank Dr. Norman Miller, University of Mississippi, for providing the hybridoma 9E1 and Dr. Joseph Newton, Auburn University, for providing the purified Edwardsiella ictaluri LPS that were used in this study. We also thank Dr. Michael Burger for performing the statistical analyses and Harry Cowgill for preparing the 2D-gel figures.

\section{LITERATURE CITED}

Alefounder PR, Baldwin SA, Perham RN, Shorts NJ (1989) Cloning, sequence analysis, and over-expression of the gene for the class II fructose 1,6-bisphasphate aldolase of Escherichia coli. Biochem J 257:529-534

Amend DF (1981) Potency testing of fish vaccines. Dev Biol Stand 49:447-454

Ausubel FM, Brent RE, Kingston RE, Moore DD, Seidman JG, Smith JA, Struhl K (1994) Current protocols in molecular biology. John Wiley \& Sons, New York

Baldwin SA, Perham RN, Stribling D (1978) Purification and characterization of the class II D-fructose 1,6-bisphosphate aldolase from Escherichia coli. Biochem J 169:633-641

Berry A, Marshall KE (1993) Identification of zinc-binding ligands in the class II fructose-1, 6-bisphosphate aldolase of Escherichia coli. FEBS Lett 318:11-16

Bertolini JM, Cipriano RC, Pyle SW, Mclaughlin JJA (1990) Serological investigation of the fish pathogen Edwardsiella ictaluri, cause of enteric septicemia of catfish. J Wildl Dis 26:246-252

Bollag DM, Edelstein SJ (1991) Protein methods. Wiley-Liss, New York
Collins LA, Thune RL (1996) Development of a defined minimal media for the growth of Edwardsiella ictaluri. Appl Environ Microbiol 62:848-852

Cooper RK, Shotts EB, Nolan LK (1996) Use of a mini-transposon to study condroitinase activity with Edwardsiella ictaluri. J Aquat Anim Health 8:319-324

Fleischmann RD and 39 others (1995) Whole-genome random sequencing and assembly of Haemophilus influenzae Rd. Science 269:496-512

Folkesson A, Advani A, Sakapolvi S, Pfeifer JD, Normark S, and Lofdahl S. 1999. Multiple insertions of fimbral operons correlate with the evolution of Salmonella serovars responsible for human disease. Mol Microbiol 33:612-622

Henikoff S, Haughn GW, Calvo JM, Wallace JC (1988) A large family of bacterial activator proteins. Proc Natl Acad Sci USA 85:6602-6606

Hove-Jensen B, Maigaard M (1993) Escherichia coli rpiA gene encoding ribose phosphate isomerase A. J Bacteriol 175:5628-5635

Johnson MR (1991) Bacterial resistance to antibiotics: a growing problem in the channel catfish industry. In: Reigh RC (ed) Proceedings of the Louisiana Aquaculture Conference. LA, Louisiana State University Agricultural Center, Baton Rouge, LA, p 22-23

Kaufmann SHE (1993) Immunity to extracellular bacteria. In: Paul WE (1993) Immunity to extracellular bacteria. Raven Press, New York, p 1251-1286

Klesius PH, Horst MN (1991) Characterization of a major outer-membrane antigen of Edwardsiella ictaluri. J Aquat Anim Health 3:181-187

Klesius PH, Shoemaker CA (1999) Development and use of modified live Edwardsiella ictaluri vaccine against enteric septicemia of catfish. Aquaculture 176:189-193

Lawrence ML, Cooper RK, Thune RL (1997) Attenuation, persistence, and vaccine potential of an Edwardsiella ictaluri purA mutant. Infect Immun 65:4642-4651

Levina N, Totemeyer S, Stokes NR, Louis P, Jones MA, Booth IR (1999) Protection of Escherichia coli cells against extreme turgor by activation of $\mathrm{MscS}$ and MscL mechanosensitive channels: identification of genes required for MscS activity. Embo (Eur Mol Biol Organ) J 18:1730-1737

MacMillan JR (1985) Infectious disease. In: Tucker CS (ed) Channel catfish culture. Developments in aquaculture and fisheries science, Vol 15. Elsevier, Amsterdam, p 405-496

Miller NW, Bly J, Ellsaesser CE, van Ginkel F, Clem LW (1987) Phylogeny of lymphocyte heterogeneity: identification and separation of functionally distinct subpopulations of channel catfish lymphocytes with monoclonal antibodies. Dev Comp Immunol 11:739

Moore MM, Thune RL (1999) Evaluation of the expression of immunogenic and non-immunogenic proteins of Edwardsiella ictaluri under different growth conditions using mini-2-dimensional polyacrylamide gel electrophoresis. J Aquat Anim Health 11:262-274

Mutoh N, Hayashi Y (1994) Molecular cloning and nucleotide sequencing of Schizosaccharomyces pombe homologue of the class II fructose-1,6-bisphosphate aldolase gene. Biochim Biophys Acta 1183:550-552

Neter J, Wasserman W, Kutner MH (1990) Applied Linear statistical models: regression, analysis of variance, and experimental design. Irwin, Boston

Newton JC, Triche PL (1993) Electrophoretic and immunochemical characterization of lipopolysaccharide of $E d$ wardsiella ictaluri from channel catfish. J Aquat Anim Health 5:246-253

Plumb JA (1988) Vaccination against Edwardsiella ictaluri. 
In: Ellis AE (ed) Fish vaccination. Academic Press, London, p 152-161

Plumb JA, Vinitnantharat S (1989) Biochemical, biophysical, and serological homogeneity of Edwardsiella ictaluri. J Aquat Anim Health 1:51-56

Plumb JA, Wise ML, Rogers WA (1986) Modulary effects of temperatures on antibody response and specific resistance to challenge of channel catfish (Ictalurus punctatus) immunized against Edwardsiella ictaluri. Vet Immunol Immunopathol 12:297-304

Saeed MO, Plumb JA (1986) Immune response of channel catfish to lipopolysaccharide and whole cell Edwardsiella ictaluri vaccines. Dis Aquat Org 2:21-26

Sambrook J, Fritsch EF, Manniatis T (1989) Molecular cloning: a laboratory manual, 2nd edn. Cold Spring Harbor Laboratory Press, Cold Spring Harbor, NY

Schwelberger HG, Kohlwein SD, Paltauf F (1989) Molecular cloning, primary structure and disruption of the structural gene of aldolase from Saccharomyces cerevisiae. Eur J Biochem 180:301-308

Scott AL, Rogers WA, Klesius PH (1985) Chemiluminescence by peripheral blood phagocytes from channel catfish Ictalurus punctatus: function of opsonin and temperature. Dev Comp Immunol 9:241-250

Sheldon WMJ, Blazer VS (1991) Influence of dietary lipid and temperature on bactericidal activity of channel catfish macrophages. J Aquat Anim Health 3:87-93

Shoemaker CA, Klesius PH, Plumb JA (1997) Killing of Edwardsiella ictaluri by macrophages from channel catfish immune and susceptible to enteric septicemia of catfish. Vet Immunol Immunopathol 58:181-190

Snyder L, Champness W (1997) Molecular genetics of bacteria. American Society for Microbiology, Washington, DC

Stribling D, Perham RN (1973) Purification and characterization of 2 fructose diphosphate aldolases from Escherichia coli. Biochem J 131:833-841

Stryer L (1988) Biochemistry. Freeman \& Co, New York

Thoney B, Hwang DS, Fradkin L, Komberg K (1991) iciA, and Escherichia coli gene encoding a specific inhibitor of chromosomal replication in vitro. Proc Natl Acad Sci USA 88: 4066-4070

Editorial responsibility: Carey Cunningham, Aberdeen, Scotland, UK
Thune RL, Hawke JP, Johnson MC (1993) Studies on vaccination of channel catfish, Ictalurus punctatus, against Edwardsiella ictaluri. In: Tave D, Tucker CS (eds) Recent developments in catfish culture. Food Products Press, Binghampton, NY, p 11-23

Thune RL, Collins LA, Pena MP (1997a) A comparison of immersion, immersion/oral combination and injection methods for the vaccination of channel catfish Ictalurus punctatus against Edwardsiella ictaluri. J World Aquacult Soc 28:193-201

Thune RL, Hawke JP, Fernandez DH, Lawrence ML, Moore MM (1997b) Immunization with bacterial antigens: edwardsiellosis. Dev Biol Stand 90:125-134

Thune RL, Fernandez DH, Battista JR (1999) An aroA mutant of Edwardsiella ictaluri is safe and efficacious as a live, attenuated vaccine. J Aquat Anim Health 11:358-372

Tyler JW, Klesius PH (1994a) Protection against enteric septicemia of catfish (Ictalurus punctatus) by immunization with the R-mutant, Escherichia coli (J5). Am J Vet Res 55: $1256-1260$

Tyler JW, Klesius PH (1994b) Specificity of humoral responses of convalescent channel catfish of Edwardsiella ictaluri. J Aquat Anim Health 6:271-274

Vinitnantharat S, Plumb JA (1993) Protection of channel catfish Ictalurus punctatus following natural exposure to Edwardsiella ictaluri and effects of feeding antigen on antibody titer. Dis Aquat Org 15:31-34

Waterstrat PR, Ainsworth AJ, Capley G (1991) In-vitro responses of channel catfish, Ictalurus punctatus, neutrophils to Edwardsiella ictaluri. Dev Comp Immunol 15: 53-64

Wise DJ, Tomasso JR, Schwedler TE, Blazer VS, Gatlin DM III (1993) Effect of vitamin $E$ on the immune response of channel catfish to Edwardsiella ictaluri. J Aquat Anim Health 5:183-188

Zhang HG, Hanson LA (1995) Deletion of thymidine kinase gene attenuates channel catfish herpesvirus while maintaining infectivity. Virology 209:658-663

Zhang HG, Hanson LA (1996) Recombinant channel catfish virus can express foreign genes and induce antibody production against the gene product. J Fish Dis 19:121-128

Submitted: August 1, 2001; Accepted: May 6, 2002

Proofs received from author(s): October 18, 2002 